\title{
PARA-LEGAL AUTHORITY AND ITS PERILS
}

\author{
ROBERT L. BOROSAGE* \\ INTRODUCTION
}

When Richard Nixon invoked a national security prerogative to decide for peace or war, to make and fulfill secret commitments for the nation, to wiretap or break and enter, and to maintain absolute secrecy, he could refer to twenty-five years of executive practice justified by the leading lawyers of our time. Not surprisingly, the growth of executive power has been rationalized by legal argument. Three primary doctrines-inherent power, congressional delegation and post hoc ratification-have been employed within the executive branch to justify executive initiative without legislative authority. Although seldom reviewed and more rarely adopted in Supreme Court decisions, these arguments provide the para-legal authority upon which broad segments of the bureaucracy operate. Although Nixon's excesses have given pause to the expansion of presidential prerogatives, continued assertions of para-legal authority are inevitable, if only to justify on-going activities. This paper uses a recent example of this assertion-the legal justification of covert action by the Central Intelligence Agency-to outline somewhat mechanically the logic and effect of the justification, and to comment on the limits of reform in such a situation.

The warfare bureaucracies, like the welfare agencies of the New Deal, were the offspring of emergency, justified by necessity, that doctrine of "pernicious consequences," in the words of Justice Davis. ${ }^{1}$ In both cases, emergency became routine. Since the modern economy requires constant tending by the state, the executive powers and agencies developed in response to the Depression have become permanent features of the political landscape. Similarly, the cold war made permanent place for the institutions and powers developed to fight World War II. Indeed, belligerancy itself has become routine. Since 1948, the United States has been involved in major crisis about once every eighteen months-Greece, Iran, Korea, Lebanon, Guatemala, the Congo, Cuba, the Dominican Republic, Vietnam, Laos, Cambodia, Angola - the list extends to every cranny in the world. ${ }^{2}$

An interventionist state must inevitably diminish the power of its legislative body and increase that of the executive. Secretary of State Dean Acheson was

\footnotetext{
* Director, Center for National Security Studies, Washington, D.C.

1. Ex Parte Milligan, 4 Wallace 2, 120-21 (1866).

2. See Barnet, Intervention and Revolution 11 (1968).
} 
fond of quoting DeTocqueville's warning that "foreign politics demand scarcely any of those qualities which are peculiar to a democracy .... [A democracy] cannot combine its measures with secrecy or await their consequences with patience. These are qualities which more especially belong to an individual or an artistocracy" 3 or, in the United States, to an executive bureaucracy. Thus in postwar United States the power of initiative, the ability to set the direction and to marshal the resources of the society, passed to the Executive. The notion that the President may act if not limited by CongressTheodore Roosevelt's "stewardship theory" writ large-is virtually unquestioned in areas of national security. The argument is rather over the Stuart theory, summarized by Locke's description of the prerogative as "the power to act according to discretion for the public good, without the prescription of the law and sometimes even against it." 4

The growth of the executive branch naturally distorts its constitutional roots. Legal authority for the executive initiative is not easily located in the constitutional schema, or in the traditional beliefs and myths associated with the Constitution. The very first premise of the founders was that the executive was subject to law, that the executive power is the power and duty to execute laws passed by Congress. Yet, appeal to the law is desirable to even the most powerful, for it provides a cloak of traditional authority for his activities. Thus, over the years, executive spokesmen have recurrently, often tenuously, asserted a legal authority for presidential initiative on the basis of the inherent power of the President, by reference to some congressional statute, or by claim of congressional ratification. These doctrines, as Robert Nisbet has said, have been employed to justify "every conceivable degree of power, stealth, and cunning." 5

Not surprisingly, these arguments gained in popularity in the late forties and fifties. The smouldering dispute between the Congress and the President over executive privilege which dated back to the first years of the republic was inflamed by the memorandum of Attorney General Rogers during the Eisenhower Administration, which claimed for the President an "uncontrolled discretion" to withhold information. ${ }^{6}$ The modern claim of a foreign policy prerogative was grandly intoned, ex cathedra, by Secretary of State Dean Acheson, who preached that the President's "authority to use the Armed Forces in carrying out the broad foreign policy of the United States . . may not be interfered with by the Congress in the exercise of powers which it has under the Constitution." "Hannah Arendt noted that Eisenhower was the last

3. Quoted in D. Acheson, Private Thoughts on Public Affalrs 55 (Harvest Book ed. 1955).

4. Quoted in E. Corwin, The Constitution and What it Means Today 112 (Chase \& Ducat ed. 1973).

5. R. Nisbet, Twilight of Authority 31 (1975).

6. See Berger, Executive Privilege v. Congressional Inquiry, 12 UCLA L. REv. 1034, 1045 (1965).

7. Quoted in S. REP. No. 606, 92d Cong., 2d Sess. 17 (1972). 
President to believe that the initiation of a war required prior consent of Congress. ${ }^{8}$ The New York Times revealed that the first 150 years of the republic witnessed 799 treaties and 1,182 executive agreements; the next twenty-six featured 368 treaties and 5,590 executive agreements, with 400 additional covenants secreted even from the Congress. ${ }^{9}$ The FBI traces its internal security and wiretap powers back to an executive order by Franklin Roosevelt, which was renewed by President Truman. ${ }^{\prime \prime}$

Taken together, the three legal doctrines provide an opportune post facto justification for executive actions initiated essentially without concern for the limits of law. They provide the para-legal rationale for ongoing bureaucratic activity. The President is said to have residual powers in the area of foreign relations. The scope of these powers is not defined, but may be divined from "the gloss which life has written" on the Constitution. " Repeated presidential acts may establish a new inherent power in the Chief Executive of constitutional dimension, a claim which Raoul Berger has termed "adaptation by usage." 12 Alternatively, ongoing bureaucratic activities are said to be ratified by the Congress if it votes appropriations, even if initially unauthorized. Finally, broad or vague language in congressional authorization statutes may be pieced together to provide a peg of legal authority on which to hang executive programs. All three justifications condone and even encourage executive initiative without concern for legal limits or authority.

Our recent experience with Vietnam and Watergate provides tragic testimony to the dangers posed by this reasoning. Widespread belief in raison d'etat fosters actions which trample the bounds of the Constitution. Some of its worst effects are felt in the law itself. Increasingly, law becomes viewed as voluntas, the mere whim of the powerful. The national security bureaucracies increasingly act for the purposes of the state, assuming that the law presents no limitation. Within the bureaucracy, legal authority is the mere will of the President, or the orders of a bureaucratic superior. Only to outside queriesto the citizenry, the courts and the Congress-are traditional legal doctrines sent to the lists. Para-legal justification may thus represent a transitional form between the rule of law and the reign of a leader. Clearly the removal of constitutional restraints paves the way for decisionism, the acceptance of political decisions no matter what their content as long as sufficient power stands behind them.

To be more concrete, bureaucratic programs and actions operate upon the

8. H. Arendt, Crises of the Republic 21 (1969).

9. New York Times, May 1, 1972, at 32, col. 1.

10. Senate Select Comm. to Study Governmental Operations with Respect to Intelligence Activities, 94th Cong., Ist Sess., Final. Report, Book // 22 (1976).

11. Youngstown Sheet \& Tube Co. v. Sawyer, 343 U.S. 597. 610 (1952) (Frankfurter, J., concurring).

12. Berger, War-Making by the Presidemt, 121 U. PA. L. Rev. 29, 54 (1972). 
legal opinions of lawyers within the executive branch. Seldom do these assertions come within the purview of the courts or raise the ire of the legislature. Thus, the internal papers of executive "house counsel" are of great "legal" effect, for activities cloaked with the authority of the state proceed on their authority. Executive attorneys are expected to find authority for activities, not restrain them. The development of legal justifications thus provides a veneer of legality for executive initiative. I would argue that the repeated (often cynical) employment of such doctrines slowly erodes the concept of law as separate from will, both procedurally (the legislature must empower) and substantively (there are constitutional limits which must be obeyed). Moreover, after twenty-five years of such practice, reconstitution and reform are most difficult.

The continuing, post-Watergate usage of such doctrines is best illustrated in the recent dispute over the Central Intelligence Agency and its covert action programs abroad. The CIA's distinguished outside counsel, Mitchell Rogovin, filed a brief with the Senate and House Select Investigating Committees which advanced the three archetypal justifications for executive initiative in defense of covert action abroad. ${ }^{13}$ The importance of the subject, the exemplary nature of the arguments, and the reputation of the author make the brief itself worthy of perusal.

The Cia's Covert Action: The law as a Cloak

"Covert Action" is the bureaucratic euphemism for clandestine operations, beyond the gathering of intelligence, which are designed to influence the internal affairs of other nations. Richard M. Bissell, Deputy Director of Plans between 1958 and 1962, provided the following typology of covert action to a private briefing sponsored by the Council on Foreign Relations in 1968:14

The scope of covert action could include: (1) political advice and counsel; (2) subsidies to an individual: (3) financial support and "technical assistance" to political parties; (4) support of private organizations, including labor unions, business firms, cooperatives, etc.: (5) covert propaganda; (6) "private" training of individuals and exchange of persons: (7) economic operations; and (8) paramilitary [or] political action operations designed to overthrow or 10 support a regime (like the Bay of Pigs and the programs in Laos). These operations can be classified in various ways: by the degree and type of secrecy required, by their legality, and, perhaps, by their benign or hostile character.

In the balder language of criminal law, covert action would encompass bribery, forgery, libel and slander, arson, mayhem and conspiracy to commit

13. Hearings Before the House Setect Comm. on Intelligence, 94th Cong. 1st. Sess., Part 5, 1729-38 (1976) (hereinafter cited as Rogoinin Memorandum).

14. Quoted in J. Marks and V. Marchetti, The Cla and the Cult of Intellgence 387 (1974). 
a range of felonies, including kidnapping, murder, riot and insurrection. The CIA's activities range from day-to-day manipulation to sponsoring and directing clandestine armies in Laos and Angola.

As Senator Frank Church has suggested, "[t]he legal basis for this political action arm of the CIA is very much open to question." 15 Inspection of the Agency's legislative charter and its legislative history provides not a word about covert action. Legal authority was not of great concern until the wide range of CIA illegalities and abuses received publicity. In recent debates over the CIA, critics and defenders of the agency have sought to enlist the law as an ally in the political struggle. The Rogovin Memorandum represents the most comprehensive effort of the CIA to locate a legal basis for covert action. The memorandum canvasses three "fundamental sources" of legal authority, "each of which, in itself, constitutes a sufficient legal basis for the delegation." The three include (1) "the inherent constitutional power of the President;" (2) congressional authorization; (3) congressional ratification. ${ }^{16}$

\section{A. Inherent Power}

Although the precursor of the expanded national security powers of the President was the developing corporate economy and the corresponding growth of welfare and regulatory powers, a broad claim of "inherent power" is rarely made in domestic affairs. Even in emergencies, Presidents have generally sought some legislative authorization before acting. ${ }^{17}$ Truman's experience in the Steel Seizure case indicates judicial sensitivity to a claim of presidential prerogative at home. ${ }^{18}$

Mr. Justice Jackson's concurring opinion in Youngstown, defined a twilight area in which the President may act in the absence of congressional pre-emption. ${ }^{19}$ The theory provides a charter for doing "anything that the needs of the Nation demanded unless such action was forbidden by the Constitution or by the laws." "2" From this right of initiative developed the claim of "adaptation by usage," that a long-term practice by the President establishes an inherent power to act, even-say advocates of its most extreme form -against a later congressional limitation. The courts have justifiably been chary about accepting the argument for, literally interpreted, it would place the Chief Executive beyond control of the Congress and the courts. The

15. Church, Covert Action: Suampland of American Foreign Policy, transcript of speech before the Pacem in Terris IV Conference, Washington. D.C., December 4. 1975.

16. Rogotin Memorandum at 1729.

17. But see United States v. Midwest Oil Co., 236 U.S. 459 (1915).

18. Youngstown Sheet \& Tube Co. v. Sawyer, 343 U.S. 597 (1952).

19. See Corwin. The Steel Seizure Case: A Judicial Brick Without Straw, in Essays IN Constitutional Law 257 (R. McCloskey ed. 1957).

20. T. Roosevelt, Autobiography, quoted in E. Corwin, The President: Office and Powers, 1787-1957: History and Analysis of Practice and Opinion 153 (4th rev. ed. 1964) (hereinafter cited as Corwin, The President). 
theory provides a favorite argument by executive spokesmen; it is used internally to justify practices initiated without authorization, and externally to impede restrictive congressional legislation. The constitutional merits of the doctrine have been debated extensively elsewhere. ${ }^{21}$ The opinion of the Court in Powell v. McCormack provides a curt rejoinder: to a congressional claim that Rep. Powell's exclusion was supported by long practice, the Court replied, "[ $\mathrm{t}$ ]hat an unconstitutional action has been taken before surely does not render that same action any less unconstitutional at a later date." 22

The power of the President to engage in covert action abroad will not, of course, be located in the enumerated powers assigned the Chief Executive in the Constitution, nor will it be supported by the debates of the founders or the decisions of the Supreme Court. The Rogovin Memorandum predicates an inherent power for covert action upon the "President's broad powers with respect to the conduct of foreign affairs." The President's broad powers are established by passing reference to judicial dicta and historical quotations. That these powers encompass covert action is proven by appeal to the "overwhelming historical precedents." 23

Beginning with Marshall's general statement that the "President is sole organ of the nation in its external relations," the Memorandum skips down the well-trod path of excerpts from the Senate Foreign Relations Committee Report of 1816 and Mr. Justice Sutherland's dicta in United States v. CurtissWright Export Corporation. ${ }^{24}$ Although the Supreme Court has never considered the question directly, the Rogovin Memorandum suggests that the Court would uphold the President's inherent right "to direct an agency of government to perform covert action abroad," having made it clear that the President has the right to conclude binding executive agreements, ${ }^{25}$ to use military force abroad to protect United States citizens, ${ }^{26}$ and to repel an armed attack by meeting "force with force." 27

Review of the authorities cited in the Rogovin Memorandum to establish a broad presidental power over foreign affairs is not necessary here. ${ }^{28}$ Even

21. Compare Rostow, Great Cases Make Bad Law: The War Powers Act, 50 Texas L. Rev. 833 (1972) with Berger, supra note 12.

22. Powell v. McCormack, 395 U.S. 486, 546-47 (1969).

23. Rogotin Memorandum at 1731 .

24. Id. at $1730-31$.

25. United States v. Pink, 315 U.S. 203 (1942).

26. In re Neagle, 135 U.S. I (1890).

27. The Prize Cases, 67 U.S. (2 Black) 635 (1862).

28. Marshall's address was concerned with the President's right to represent the country in foreign affairs, being responsible for receiving Ambassadors and carrying on negotiations. The same is true of the Senate Report. Curtiss-Wright involved, as Justice Jackson noted in Youngstoun, "Not the question of the President's power to act without congressional authority, but the question of his right to act under and in accord with an Act of Congress. . ." 343-U.S. at 635-6; the rest is dicta. See generally Berger, The Foreign Policy Powers of the President, 1 Mich. L. Rev. I (1972). In re Neagle involved the President's police power at home, not the war power abroad. See generally: Wormuth, The Nixon Theory of the War Pouer: A Critique, 60 Cal. L. Rev. 623 (1972). 
assuming expansive powers, it would be difficult to invent a practice more foreign to the Constitution than routine covert intervention in the internal affairs of other countries. The Rogovin Memorandum's invocation of inherent power thus rests almost entirely on the "overwhelming historical precedents."

What is the evidence of a traditional practice so accepted as to place the "gloss of life" on the Constitution? The Rogovin Memorandum cites two areas of experience. First is the "longstanding practice whereby Presidents, acting on their own authority, have dispatched troops to foreign countries and authorized the use of military force short of war. . ."29 In this regard, the Memorandum cites the hoary list of 125 instances compiled by the Library of Congress in 1920. "It would logically follow," the Memorandum concludes, that the President therefore has the power to "send civilian personnel to foreign countries to engage in covert action." 3 "

The War Powers Resolution of 1973 indicates that any presidential inherent power to dispatch troops abroad can at least be regulated by the Congress. ${ }^{31}$ Of the 125 incidents, the "great majority... were for the simple protection of American citizens in disturbed areas,' and only about a third involved belligerent action." 32 "Whatever their magnitude, all also had one trait in common: they involved uniformed military, acting overtly on orders of the President (or lesser military commanders). Not one involved the covert use of civilians to disrupt the internal affairs of another country.

The second line of precedents is invoked to remove this distinction. Virtually every President has appointed "special agents ... to perform what has come to be known as covert action . . . to engage in certain activities with or against foreign countries. . . "33 In the first century of the nation alone, the Memorandum reports, more than 400 of such were appointed by the President. $^{34}$ Still, the conclusion is drawn that this practice is so "deeply rooted" that historians have acknowledged the "existence of a broad presidential discretion with respect to appointment of such agents and assignment of functions to them. ${ }^{-35}$ And in support, the Rogovin Memorandum cites Henry Merritt Wriston's seminal study, Executive Agents in American Foreign Relations. ${ }^{36}$

But Wriston's study itself provides the proper tonic for the heated conclusions of the Rogovin Memorandum. Wriston concludes that, "[c]ontrary to

\footnotetext{
29. Rogorin Memorandum at 1731 .

30. Id. at 8 .

31. 50 U.S.C. $\$ \$ 1541-48$ (Supp. 1 V 1974).

32. E. Corwin. The President, at 437 n.83.

33. Rogozin Memorandum at 1732 .

34. Id. Also cited are two congressional reports, both of which are also cited by Wriston, infra note 36 .

35. Id. at 1733

36. H. Wriston, Executive Agents in American Foreign Relations (1929) (hereinafter cited as WRISTON).
} 
general belief, the amount of 'secret' service in American diplomacy is relatively small." 37 He presents a handful of examples which include the three cited in the Rogovin Memorandum. What of the 400 agents in the first hundred years or the "legion" of precedents cited in the Memorandum? These refer to special agents selected by Presidents to represent them abroad. Wriston gives them two general characteristics: they are agents of the President rather than officials of the government- "They have an employment, not an office"; their duties are generally special and temporary. ${ }^{38}$

The "characteristic situations" in which special agents have been used include: "ceremonial occasions;" to speak for the President personally; international conferences and delegations (the "most prolific" source); contacts with unrecognized states; technical matters requiring a high degree of expertness. In effect, then, the Rogovin Memorandum would have us consider the dispatch of Chief Justice Warren to DeGaulle's funeral as a precedent for covert action. In contrast, however, Wriston himself concludes that "episodes in the eighteenth and nineteenth centuries could be adduced, but they would be rare, and, for the most part, not significant, and certainly not typical. . .."39

This is the longstanding practice from which the Rogovin Memorandum would derive a constitutional power for the President to employ a secret agency in widespread covert operations abroad. More than a difference of degree reaching a difference in kind, it is rather a simple form of sophistry to justify this dangerous agency on the basis of an inapposite tradition. The tortured logic of the Memorandum was not forwarded without reason, however. The CIA traces its birth back to an executive order issued by President Roosevelt in 1941, establishing the Office of Coordination and Information in the White House. Roosevelt issued the order four months before Pearl Harbor on the basis of "the authority vested in me as President of the United States and as Commander in Chief of the Army and Navy of the United States. . ." El" Even months later, OCI became the Office of Strategic Services, a transformation directed by "military order," and OSS undertook both clandestine intelligence collection and para-military operations (covert action) throughout the war. ${ }^{41}$

In 1945, OSS was disbanded by executive order, but four months later President Truman established the National Intelligence Authority and the Central Intelligence Group by a "Presidential Directive" issued without any proclaimed basis in law. The directive authorized the CIG to plan, develop and coordinate "such other functions and duties related to intelligence affect-

37. Id. at 693 .

38. Id.

39. Wriston, The Special Envoy, 38 For. Affairs 219, 226 (1960).

40. Roosevelt, Letter of July 11, 1941, 3 C.F.R. 1324 (1938-43 Comp.).

41. See generally R.H. SMITH, OSS (1972). 
ing the national security as the President . . . may from time to time direct., ${ }^{42}$ Thus, the CIA's immediate forbearers were established by executive orders issued in peacetime. Although the CIG reportedly had no covert action arm, the Rogovin Memorandum claims, for reasons discussed below, that it did engage in such activities. Only some notion of inherent power can legitimate this activity post facto. The Rogovin Memorandum seeks to legitimate this ancestry by inventing a birthright in inherent power. ${ }^{43}$

\section{B. Authorization and Delegation}

The primary source for the expansion of executive power has been the sweeping delegations of power made by Congress in the passage of broad and vague statutes. Although receiving frequent judicial tribute in dicta, the constitutional doctrine prohibiting the delegation of legislative power, as Elihu Root noted as early as 1916, "has virtually retired from the field and given up the fight. . ."44 This is true particularly in foreign affairs; Cutiss-Wright was (or should have been) a delegation case, and Mr. Justice Sutherland's opinion has been cited for the proposition that "Congress-in giving the Executive authority over matters of foreign affairs-must of necessity paint with a brush broader than it customarily wields in domestic areas. . ."45 Vague legislation combined with the demise of the delegation doctrine has practical effects. The congressional intent in a statute-other than an intent not to set policy-is difficult to divine for either an administrator or a court sitting in review. The very scope of the authorization, as well as the authority to act within the scope, is often unclear.

Often executive agents define not only policies which come under a legislative commission, but also the meaning and scope of the commission itself. ${ }^{46}$ For all branches of the government, and for the citizenry, agency practice provides the predominant definition of the legislative grant. In the social welfare and regulatory agencies, this power is bounded to some degree by administrative law, the system of formalized public rule-making and internal due process, which Congress can review if it chooses. ${ }^{47}$ In the national security bureaucracies, secrecy limits oversight, and as the next section will show,

42. Presidential Directive of Jan. 22, 1946, 3 C.F.R. 1080 (1943-48 Comp.).

43. The decision not to seek legislation was made, according to Bernard Gladieux. who drew up the papers in 1945, in part because, "Congressional mood was such that it wouldn't even have gotten out of committee." Bernard Gladieux, Interview with David Klaus, Washington, D.C., May 19, 1975, Notes on file at Center for National Security Studies, Washington. D.C.

44. Quoted in K. Davis, Administrative Law 36 (2d ed. 1959).

45. Zemel v. Rusk, 381 U.S. 1, 17 (1965).

46. Compare Alexander Hamilton: "A delegated authority cannot alter the constituting act ... . An Agent cannot new-model his own commission. . . Quoted in Berger, supra note 12 at 57 (emphasis deleted).

47. See generally K. Davis, Discretionary Justice: A Preliminary Inquiry (1969); Jaffe, An Essay on Delegation of Legislative Power, 47 Colum. L. Rev. 359 (1947). 
formal bureaucratic procedures often do not apply. Additionally, executive officers assume far greater license in national security matters. In this area, the legal process quickly becomes inverted. Instead of a congressional charter commissioning executive practice, the latter begins independently, and administration attorneys search out a possible legislative basis, treating the Federal Code as a clothing store of authority, in which different laws may be tried on at will. The Rogovin Memorandum, reflecting the claims of Central Intelligence Agency spokesmen, represents an extreme example of this inversion.

The Central Intelligence Agency was established formally by the National Security Act of $1947 .{ }^{48}$ The Act briefly outlined the functions of the new agency-coordination, development and analysis of intelligence. The charter contains no explicit authority for either the collection of intelligence or for covert action abroad. Clause (5) of Section 102(d), the "other functions" clause, authorizes the agency "to perform such other functions and duties related to intelligence affecting the national security as the National Security Council may from time to time direct."4!" It is this clause which agency spokesmen claim authorizes covert action abroad. The clause was adopted virtually verbatim from the 1946 Truman executive order establishing the Central Intelligence Group, as was the entire CIA charter." It was generally assumed that the Central Intelligence Agency would perform the functions previously discharged by the CIG.

The Rogovin Memorandum argues that the House Committee on Expenditures in Executive Departments, with "full knowledge of the broad implications of subparagraph (d) of the 1946 Presidential Directive, conferred identical powers and responsibilities on the CIA," including "a broad range of operational assignments." ${ }^{1} 1$ "Operational assignments" in the CIA lexicon sometimes includes both covert action and human intelligence collection (espionage), and sometimes refers only to espionage. Its definitional flexibility is used frequently to obscure and impede outside oversight efforts. ${ }^{52}$ The Rogovin Memorandum claims that the CIG was involved in covert action abroad, that the House Committee and Congress knew this, and that the "fifth function" clause encompassed it. All three propositions are confounded by the record.

CIG was an interim agency, a "short-term pip-squeak thing," noted Arthur

48. Pub. L. No. 80-253, 61 Stat. 495 (codified at scattered sections of 5, 10, 31 and 50 U.S.C. but largely repeated).

49. 50 U.S.C. $\$ 403(1970)$.

50. Initially the National Security Act contained a section stating that the CIA would undertake all the functions contained in Presidential Directive of Jan. 22. 1946. 3 C.F.R. 1080 (1943-48 Comp.). The House Committee demanded a spelling out of the functions.

51. Rogovin Memorandum at 1735 .

52. See Wise, Conert Operations Abroad: An Overview, in The CIA File (Borosage \& Marks ed. 1976). $9-10$. 
Macy Cox, a former employee of both CIG and CIA. ${ }^{53}$ There is no historical evidence that CIG had any covert action programs. Cox and Lawrence Houston, General Counsel of the CIA for over twenty years, both stated that the CIG has no such projects. ${ }^{54}$ In both the House and the Senate, CIG was described in public record as a coordinating and analytical agency. There were rare and passing references to intelligence collection; covert action was not mentioned. ${ }^{55}$

The same descriptions were provided for the proposed functions of the CIA in the public hearings of the House and Senate-scattered reference to intelligence collection, no mention at all of covert action. ${ }^{56}$ The Rogovin Memorandum quotes an exchange between Representative Brown and Lt. General Hoyt Vandenberg, then Director of Central Intelligence, as authority for imputing congressional knowledge of and intent to authorize covert action. The Memorandum fails to indicate that the exchange took place in executive session, the minutes of which are classified to this day. ${ }^{57}$ With a private store of material from which to quote selectively, the Memorandum publishes the following exchange: ${ }^{58}$

Rep. Brown: "[T]his other section (i.e. subparagraph (d)) was so broad that you could do about anything that you decided was either advantageous or beneficial, in your mind?"

Lt. Gen. Vandenberg: "Yes, sir."

Rep. Brown: "In other words, if you decided you wanted to go into direct activities of any nature, almost, why, that could be done?"

Lt. Gen. Vandenberg: "Within the foreign intelligence field, if it was agreed upon by all of the three agencies concerned [i.e., State, War and Navy, the three agencies represented on the NIA]."

Vandenberg limits his response to "the foreign intelligence field," and it must be so limited, for otherwise the quote would be authority for "activities of any nature, almost. ..." In fact, the exchange referred only to the covert collection of intelligence. Walter Phorzheimer, legislative counsel with the OSS,

53. Interview with David Klaus, Washington, D.C., January 20, 1975, on file at the Center for National Security Studies, Washington, D.C.

54. Interviews with David Klaus, Washington, D.C., April 10, 1975, on file at the Center for National Security Studies, Washington, D.C.

55. Indeed, Allen Dulles was concerned by the public debate that the CIA might not receive authorization for espionage. In a letter to the Senate Armed Services Committee. Dulles wrote "Having this conception of the task... I am skeptical as to the wisdom or adequacy of the provision in the bill.... These provisions seem to me to set up what, in effect, is likely to become merely a coordinating agency for military intelligence services. . . This is useful . . but it is not enough." Dulles, Memorandum Re: Section 202, Legislative History of the CIA, (1975: Congressional Research Service) CRS-46.

56. Id. passim.

57. A recent attempt to gain access to the minutes was rebuffed by both the House Select Committee on Intelligence and the Office of the Special Counsel of the CIA. A Freedom of Information Act request is still pending.

58. Rogonin Memorandum at 1734. 
CIG, and CIA, stated that Vandenberg testified in executive session about intelligence collection, because Army Intelligence (G-2) was opposed to the CIA undertaking any collection activities. According to Phorzheimer, covert action was not mentioned. ${ }^{54}$ Lawrence Houston, who drafted the 1946 executive order, stated that the policy within the administration was "completely unclear" about covert action, and the fifth function clause was to "leave a door open" in case of the "unforeseen." $"$ " The first director of the CIA, Admiral Roscoe Hillenkoetter stated he had no interest in covert action, and intended the CIA to be purely and "intelligence outfit." 61 The language of the fifth function clause itself, as well as the entire public legislative record may be taken at least as easily against, as for, the notion that Congress intended to authorize covert action in 1947.

Essentially, the Rogovin Memorandum reflects the CIA's post facto justification of covert action on the basis of its 1947 Charter. The "fifth function" clause was used by administration officials to justify establishing covert action without a return to Congress. ${ }^{62}$ The argument of the Memorandum raises other questions which need not be pursued here. Even assuming congressional intent, what an extraordinary delegation is here! Can it be constitutionally permissible for Congress to delegate the authority to "undertake such other functions related to intelligence affecting the national security," and ranging in practice from bribery to attempted assassination to secret warmaking, thus trespassing on the congressional war power? Creation of a clandestine agency for covert intervention abroad is a perilous venture for a republic, as we have witnessed in recent days. At the very least, it is one of "these important subjects" which Congress must clearly determine. ${ }^{63}$

\section{Ratification}

When the President undertakes an action that may lawfully be done only by Congress, Congress may legitimate the act by explicit justification after the fact. ${ }^{64}$ The doctrine of ratification applies both retrospectively and prospectively, legitimating the past and authorizing a continuation. It is often employed to justify the acts of administrators acting under general grants of power in social welfare agencies. ${ }^{65}$ Obviously the doctrine sanctions unauthorized initiatives, which may then receive a later ratification. In the national security area, the President has frequently claimed ratification by appropria-

59. Interviews, supra note 54 .

60. Id.

61. $I d$.

62. See, e.g., Wise, supra note 52 at $6-7$.

63. Wayman v. Southand, 23 U.S. (10 Wheat.) 1, $41-2$ (1825).

64. See Fleming v. Mohawk Co., 331 U.S. 111 (1947); Brooks v. Dewar, 313 U.S. 354 (1941).

65. Id. 
tion acts, a position accepted by some circuit courts reviewing the Vietnam War. ${ }^{66}$

Generally the courts require an "explicit designation": an appropriation act "must plainly show a purpose to bestow the precise authority which is claimed." 67 The rationale for the requirement is clear: Executive branch appropriations are passed in comprehensive bills. The requirement insures that ratification will receive individualized attention, and thus represent a policy judgment of the Congress upon which a court may justifiably rely.

The Rogovin Memorandum presents two separate ratification claims for covert action. For the first, the Memorandum adopts the position of a 1962 Justice Department paper which concluded that continued appropriations combined with periodic reporting about covert action to selected leaders in the Congress constitutes ratification: "The Congress as a whole knows that money is appropriated to the CIA and knows generally that a portion of it goes for clandestine activities, although knowledge of specific activities is restricted. . . ."68

The Rogovin Memorandum cites Brooks v. Dewar as authority for the proposition that, under these conditions, Congress has "effectively ratified the authority of the CIA to plan and conduct covert action. . ." ${ }^{69}$ Brooks involved a challenge to a licensing scheme established by the Secretary of the Interior under a statute delegating broad responsibility of cattle-grazing districts to him. Although the licensing scheme was not explicitly authorized, the court found congressional ratification of the Secretary's activity. First, the court ruled that " $[\mathrm{t}] \mathrm{h}$ information in the possession of Congress was plentiful. . ."70 It cited annual reports of the Secretary, reported testimony at Appropriations Committe hearings, and testimony on the floor of Congress. Second, the court found that the "repeated appropriations of the proceeds of the fees thus covered, and to be covered, into the Treasury . . . constitutes a ratification of the action . . . .71

Compare the Brooks standard with the CIA's practice. The CIA's annual budgetary figures are secreted in the defense budget. Even the gross sum is not revealed to members of Congress, a practice itself of doubtful constitutionality. ${ }^{72}$ Generally, only a handful of senior legislators on appropriations subcommittees in each house are privy to some breakdown of the figure. No annual reports are issued by the Director of the Central Intelligence Agency. No open hearings and few floor debates review the activities of the

66. See Massachusetts v. Laird, 451 F.2d 26 (1st Cir. 1971).

67. Ex Parte Endo, 323 U.S. 283, 303 (1944).

68. Rogorin Memorandum at 19.

69. Id.

70. 313 U.S. $354,360-61(1941)$.

71. Id.

72. See generally Note. The CIAs Secret Funding and the Constitution, 84 YaLE L.J. 608 (1975). 
CIA. Clearly after 1960, legislators knew or should have known about the CIA's covert action capability, but that was far removed from the information available on cow-pasture licensing in Brooks. Moreover, no "explicit designation" was or could be made, for the Congress never voted on a CIA budget, much less one for covert action. The Justice Department brief cited by the Rogovin Memorandum dismisses this impediment: ${ }^{73}$

Since the circumstances effectively prevent the Congress from making an express and detailed appropriation for the activities of the CIA, the general knowledge of the Congress, and specific knowledge of responsible committee members ... are sufficient to render this principle [ratification] applicable.

Since explicit designation is inconvenient, it is not necessary. Secret appropriations are thus to have greater probative value than public ones in determining congressional ratification. Lewis Carroll might have got on well in this day.

Finally, in its second claim of congressional ratification, the Rogovin Memorandum comes to rest on a clear and concise authority. In the wake of revelations about the "de-stabilization" of Chile in December 1974, the Congress passed the Ryan Amendment to the Foreign Assistance Act of 1961. ${ }^{74}$ The relevant section provides that "no funds appropriated under any act may be expended by or on behalf of the Central Intelligence Agency for operations in foreign countries, other than activities intended solely for obtaining necessary intelligence," unless the President finds that each such operation is "important to the national security," and "reports, in a timely fashion a description" to the appropriate committees of the Congress. ${ }^{75}$ "Ironically," reported the Association of the Bar of the City of New York, "the only clear Congressional authorization for the CIA to conduct covert activities resulted from an attempt to limit those activities." 76

The Ryan Amendment graphically illustrates the congressional dilemma posed by unauthorized executive initiatives: the attempt to limit an unchartered practice is transformed into an authorization for it. Thus, the War Powers Bill is said to legitimate presidential war-making; ${ }^{77}$ the Freedom of Information Act to authorize the classification system; ${ }^{78}$ the Omnibus Crime Control and Safe Streets Act to recognize national security wiretapping. ${ }^{79}$ Congressional inaction may be claimed as evidence of an "inherent" executive power; congressional action generally co-opts it into ratifying the very

\footnotetext{
73. Rogotin Memorandum at 1736.

74. Foreign Assistance Act of 1961, Section 663, 22 U.S.C. $\$ 2242$ (1970).

75. Id

76. Committee on Civil Rights and the Committee on International Human Relations, Association of the Bar of the City of New York, The Central Intelligence Agency: Orersight and Accountability $15(1975)$.

77. 50 U.S.C. $\$ \$ 1541-48$ (Supp. IV 1974)

78. 5 U.S.C. $\S 552$ (Supp. IV 1974).

79. 18 U.S.C. $\$ \$ 2510-20$ (1970).
} 
practice it attempts to limit. Two factors reinforce this dilemma. First, unauthorized activity continued for any length of time develops bureaucratic and corporate interests which are politically potent. The CIA is perhaps the classic example, but executive branch practice in classification and international agreements reveal similar dynamics. Second and more important, routine unauthorized activity creates a new reality principle which is most difficult to ignore or repudiate. Congress will virtually always seek to limit rather than eliminate a routine executive activity, no matter how pernicious.

The Ryan Amendment illustrates the potency of the new reality created by unauthorized activity. The amendment can offer no satisfactory definition of covert action, except those activities performed by the CIA "other than those activities intended solely for obtaining necessary intelligence." ${ }^{\circ}$ " The category of covert action is defined in terms of the bureaucratic practice. Thus the Ryan Amendment constitutes perhaps the ultimate delegation: post hoc ratification for anything the CIA undertakes other than intelligence collection. Given the CIA's history-most of which was secret from the Congress-this could include anything from petty bribes to assassination attempts and secret wars. Given the language of the statute, it could include anything which the President found "important to the national security," which could be undertaken by the CIA through direct or indirect expenditures. The final reduction of law to decisionism occurs here: the law is defined by presidential decision, and the authority of the legislature can be cited as authorization.

II

\section{The Disorder of the Secret Bureaucracy}

The rather widespread acceptance of para-legal justifications for executive initiative undermines respect for legal authority in ways we are only now coming to understand. From the first, the growth of regulatory agencies created concern about the rule of law. Elihu Root reflected both the fear and the response in 1916: ${ }^{81}$ "If we are to continue a government of limited powers, these agencies of regulation must themselves be regulated .... The rights of citizens against them must be made plain. A system of administrative law must be developed. . . ." Administrative law, through the devices of formal rulemaking procedures, adjudicatory hearings, due process guarantees, and oversight, calmed many of the fears created by the domestic agencies. ${ }^{82}$ However much we may deplore the inherent despotism of "petty, narrow, rigid and illiberal" bureaucracy, with its "little men clinging to little jobs and striving towards bigger ones," the system of administrative law has at least provided

80. 22 U.S.C. \$ $2242(1970)$.

81. Quoted in K. Davis, supra note 44 at 12

82. Certainly not all: Many commentators agree that the growth of "substantive law" has greatly contributed to loss of authority in this country. 
the minimal protection of regularity, due process, and Weberian rationality to the social welfare and economic bureaucracies. ${ }^{83}$

The same is not true for the national security agencies. The CIA's internal operations do not follow even Weberian principles of rational legal authority. Recent revelations indicate that the CIA is far from unique in this regard; virtually every intelligence agency reviewed by the Congress is similarly patterned. Behind the veil of official secrecy, the CIA and other agencies have operated above the law.

Thus, executive agency officials essentially created their own commission. At the first meeting of the National Security Council in December 1947, the NSC issued a top secret directive authorizing the CIA to conduct covert operations. From 1955 to 1970, the basic authority for covert action was a revised and secret NSC Directive: NSC 5412/2. Defining covert operations as "any covert activities related to propaganda, economic warfare, political action (including sabotage, demolition, and assistance to resistance movements)," the directive instructed the CIA to counter " 'International Communism' throughout the world." ${ }^{4}$ In 1962, the CIA's General Counsel, Lawrence Houston, rendered an internal opinion that the Agency's activities were "not inhibited by any limitations other than those broadly set forth in NSC 5412/2."85 Early agreements with the Justice Department insured that domestic law need not be of concern; the CIA was given a prior check on any criminal investigations concerning CIA officials or agents. ${ }^{86}$

Initially, the internal decision-making and review structure for covert action was informal and ill-defined. In 1955, a formal structure was established. The Special Group, a subcommittee of the National Security Council, was chartered, and to this day this subcommittee (now called the 40 Committee) is responsible for reviewing and approving proposed activities.

The Assassination Report of the Senate Select Committee on Intelligence concluded, however, that "[a]uthorization procedures . . . have not always been clear and tidy, nor have they always been followed." 87 A 1967 internal CIA memorandum characterized procedures from 1955 to 1963 as "somewhat cloudy and ... based on value judgments by the DCI (Director of Central Intelligence)." 88 Indeed, we now know that the DCI decides which projects of the CIA are submitted to the 40 Committee, and only about one-fourth are sub-

83. Robert Michaels and Max Weber quoted in R. NisBeT, supra note 5 at 54,58 .

84. Quoted in S. ReP. No. 465, 94th Cong. 1st Sess. 9 (1975) (hereinafter cited as AssassinaTION REPORT.

85. Id.

86. The agreements are spelled out in an exchange of correspondence between Justice and the CIA in 1948, on file at Center for National Security Studies, Washington, D.C.

87. Assassination RePort at 10.

88. Id. 
mitted. ${ }^{89}$ Moreover, the Senate Committee has reported that 40 Committee procedures feature "fuzzy" criteria for evaluation, "inadequate consultation," and review which is not "searching or thorough." 90

The existence of formal procedures has not eliminated the use of informal ones. The Senate Committee reports that, "formal procedures may be disregarded by either high Administration officials or officers in the CIA."91 Thus, when President Nixon gave CIA Director Richard Helms what was, according to the Senate Report, a virtual "carte blanche" to block Allende's accession to power in Chile in 1970, he instructed Helms not to consult with the members of the 40 Committee, nor to inform the Ambassador in Chile. ${ }^{92}$ In the continuing plots to assassinate Castro involving underworld figures, CIA officials decided not to inform either the "Special Group" or a new CIA director, John McCone, about their activities. ${ }^{3}$

"Informal" procedures were reinforced by the practice of compartmentalization-internal secrecy-within the CIA. The Senate Committee traces this to the doctrine of "plausible denial", which, initially limited to taking measures to protect the United States and government officials from identification in the event of exposure of a covert operation, was soon used internally to "mask decisions of the President and his senior staff members." The Senate Report notes, "a further consequence of the expansion of this doctrine is that subordinates, in an effort to permit their superiors to 'plausibly deny' operations, fail to fully inform them about those operations." ${ }^{94}$

This practice included more than the use of aesopian language in conversations between the President and his agents. One effect was that many orders were issued orally rather than in writing. The Senate Report quotes an anonymous official involved in the assassination plots: "I don't think you are going to find a piece of paper for everything that this Agency or any other Agency has done. There are lots of things that get done by word of mouth ...."95 Indeed, written orders often are a misleading "paper trail," designed as cover for "plausible denial." When shown a damaging memorandum composed by Lawrence Houston, CIA General Counsel, General Marshall S. Carter, Deputy Director of the CIA in 1962, noted that "memorandums (sic) for the record have very little validity in fact. ${ }^{, 96}$

Two incidents portray the atmosphere in which $\mathrm{ClA}$ officials work. In October 1960, Michael Mulroney, deputy director of an "extremely secret unit in

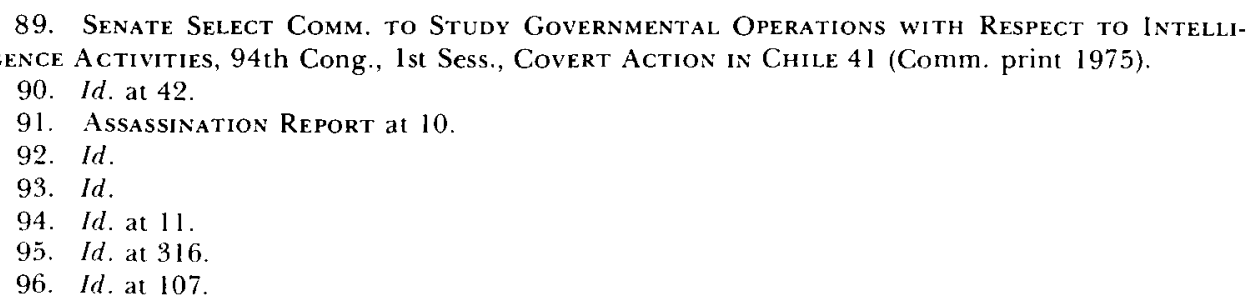


the Directorate of Plans" (Clandestine Services), was asked by Richard Bissell, at that time Deputy Director of Plans, to go to the Congo and assassinate Lumumba. ${ }^{97}$ Mulroney testified that he refused the assignment. After a second discussion with a persistent Bissell, he met with Richard Helms, at that time Bissell's deputy, and informed Helms that he refused to take the assignment. Mulroney testified about his motivation: " $[\mathrm{I}] \mathrm{n}$ the Agency since you don't have documents you have to be awfully canny and you have to get things on the record."98 The oral exchange was to protect Mulroney. For Helms, of course, the exchange might be seen as an attempt to create a record of refusal to cover actual participation (Mulroney did proceed to the Congo). Alternatively, it could be seen as an attempt to force responsibility back to Bissell. Helms asked no questions, knowing it was not his place to know the truth.

The second example is illustrated by the CIA's failure to destroy deadly toxin poisons in direct violation of a formal treaty and presidential directive. As Morton Halperin has elaborated, obviously not all treaties are intended to apply to the CIA. The Rio Pact which pledged non-interference in the internal affairs of hemispheric nations was not interpreted as a restraint on the CIA. When the President directed the destruction of the poisons, Helms received no special order to obey the directive. He might thus have assumed that he was not intended to obey (and might well have received a secret oral indication to that effect). Helms testified that he ordered his subordinates to destroy the poison, but no written order was issued. The subordinate had the same task as Helms: he had to divine if the oral order was meant to be obeyed or was simply pro forma (assuming it was actually issued), giving the subordinate responsibility for preserving the poison and bearing the blame if exposed. ${ }^{99}$ In this context, CIA officials operate not in a defined office upon written procedures with clear guidelines like a public bureaucracy, but upon what Senator Baker called "a common web of perceived authority," fulfilling what they interpret to be the intentions of their superiors. "1"1

The obvious product is the widespread assumption that the CIA is to operate above the law. CIA officials are outraged at suggestions that the "destabilization" of the Allende government was illegal because it violated United States treaties." The treaties simply do not constitute legitimate authority. Similarly, when asked why he continued the mail opening program for twenty years despite an explicit criminal statute prohibiting mail tampering, the di-

97. Id. at 38

98. Id. at 39 .

99. Halperin, CIA: Deming What's Not in Writing. New Republic, Oct. 4, 1975 at 11.

100. Assassination RePort at 319.

101. See, e.g., Statement of former CIA official Tom McCoy at Center for National Security Sudies Conference on Controlling the Intelligence Agencies. November 4. 1975. Washington. D.C., transcript on file at CNSS. 
rector of the CIA Counterintelligence Staff replied plaintively, "I find it inconceivable that a secret intelligence agency of the government has to comply with all the overt orders of the government."112 Michael Mulroney testified that after refusing Bissell's request that he assassinate Lumumba, he asked whether such plans were not a "conspiracy to commit murder . . . in the District of Columbia" and "in violation of federal law." Bissell "airly dismissed" this prospect. ${ }^{103}$

A 1954 document composed by a special presidential committee illustrates the prevalent view: it called for "an aggressive covert psychological, political and paramilitary organization far more effective, more unique, and, if necessary, more ruthless than that employed by the enemy. . . "In the new "game", "[t]here are no rules ... . Hitherto acceptable norms of human conduct do not apply ... long standing American concepts of American fair play must be reconsidered. . . ."104

This pervasive contempt for law and "fair play" was accompanied by another sensibility, less noticed in the recent revelations. Repeatedly CIA officials would display an awareness of the illegality or illegitimacy of their acts, which reinforced their furtiveness. Thus, extraordinary missions-assassinations, domestic surveillance, poison toxins-were undertaken outside of the chain of command, with oral orders and special secret task forces, whose activities were secret even from the Inspector General's office. ${ }^{105}$ When Richard Helms provided Kissinger with "Restless Youth", a CIA study on the student movement at home and abroad, he emphasized in a cover letter: "This is an area not within the charter of this Agency, so I need not emphasize how extremely sensitive this makes the paper. Should anyone learn of its existence it would prove most embarrassing for all concerned." 106 Thus, also the constant concern with the "flap potential" of the mail project, leading the CIA's Inspector General to recommend preparation of an "emergency plan," and "cover story." "1"

I suggest this demonstrates a recognition of the legal authority, if only in its conscious breach. Weber notes that "a thief orients his action to the validity of the criminal law in that he acts surreptitiously." 118 In many ways, the behavior of the CIA parallels that of a gang of thieves. Beneath the disdain and presumption was at least an expedient concern for law. This sensibility may

102. Hearings Before the Senate Select Comm. to Study Governmental Operations with Respect to Intelligence Activities, 94th Cong., 1st Sess., Vol. 2, Houston Plan (1975) (hereinafter cited as Senate Hearings).

103. Assassination Report at 39.

104. Id. at 259, n. 1 .

105. But ad hoc secret groupings were normal fare within the CIA.

106. Commission on Cia Activities Within the United States, Report to the President $134(1975)$.

107. Id. at 107

108. M. Weber, The Theory of Social. and Economic Organization (T. Parsons ed. 1964) 
well have provided the primary check on CIA officials for "even in the cases of . . . deliberate disobedience to these prescriptions, the probability of its being recognized as a valid norm may have an effect on action." 109

To a great extent, ideological zealotry-the fervent anti-communism of the Cold War-provided absolution for violations of law or "fair play." Morals were not at stake in what Dean Rusk called the "back alleys" of the world; will and manhood were. And yet the high church catechism of anti-communism could not withstand the heresy of Vietnam externally or of detente internally. The CIA's secret charter reflects the change: The basic authority of CIA covert action is now National Security Decision Memorandum 40, which superseded NSC 5412/2 on February 17, 1970. NSDM 40 describes covert actions as programs designed to further official United States policies abroad; it makes no reference to communism." ${ }^{11}$ With absolution unclear, it is not surprising that internal dissention grew. When James Schlesinger asked employees to forward information on any programs they considered illegal, he received over 500 pages in response. ${ }^{11}$ At the same time, Agency officials began to leak damaging information to the press, and one-by-one the "family jewels" were revealed. ${ }^{12}$

The para-legal operation of the CIA also has grave implications for the society's respect for law. The government, wrote Brandeis, "for better or for worse, is the great powerful teacher of its citizens." 113 One shudders to consider the lessons drawn from an Agency revealed to have engaged in assassination attempts, coups and secret wars. Because of the Agency's close connection with the criminal underground, William Colby had to deny reports that the CIA "rubbed out" Sam Giancana-a reputed Mafia chief-and his denial was widely disbelieved. The Agency operates like a conspiracy, engages in conspiracies, and represents a view of intervention and political power which is based upon conspiracy, manipulation and terrorism. One may greatly fear for a polity which so instructs its citizens. And the CIA is but a particularly seamy lesson in the course of instruction provided by a series of presidents, culminating in the televised downfall of Richard M. Nixon.

\section{Conclusion}

The foregoing has direct implications for the current period of reform and debate. For years the national security apparatus operated with the general approval of the Congress and the people. Locke long ago remarked that

109. Id. at 125.

i10. Assassination Report at 9, n.3.

111. The Washington Post. Mar. 8. 1975. at A9, Col. 1.

112. The connection between loss of authority and leaks is crucial. The CIA is now demanding Official Secrets legislation for the first ime in its history, seeking to bolster faltering purpose with legal sanctions.

113. Olmstead v. United States, 277 U.S. 439.485 (1927). 
"the people are very seldom or never scrupulous or nice in the point of questioning the prerogative whilst it is in any tolerable degree employed for ... the good of the people and not manifestly against it."114 The Vietnam War and the Nixon impeachment have spawned the furious pace of congressional, intellectual, journalistic and legal investigations of the presidency; like Caliban we suddenly rail at our image in the presidential mirror. The general assumption is that the "imperial presidency" must be brought under the limits of law, a conclusion shared even within the bureaucracy. Asked by the Senate Committee why the CIA's mail intercept program was discontinued in 1973, Howard J. Osborn, former Director of the CIA's Office of Security replied, "It came to the attention of a lot of people in the light of Watergate that the government shouldn't be doing anything illegal."115 Legislative authority is sought and reform not greatly resisted for an entire range of national security practices and institutions. Even CIA Director William Colby has announced that: ${ }^{116}$

Intelligence is American; it is being brought under our Constitution . . . The work of the Senate and House Committees ... is the process of bringing intelligence within our constitutional framework. It can be done, it will be done by better guidelines, by better supervision, and by a continued effort to keep it doing the things we Americans want it to do...

Colby's statement outlines the accepted parameters for reform. The intelligence agencies will receive new legislated charters with "strengthened" congressional oversight and presumably new reporting requirements. The War Powers Resolution, ${ }^{117}$ the Freedom of Information Act, ${ }^{118}$ the Omnibus Crime Control and Safe Streets Act, ${ }^{119}$ and the Congressional Budget and Impoundment Control Act of $1974^{121}$ will be supplemented by legislation on the intelligence agencies and on surveillance techniques. The general model will be the same: an attempt to limit executive license through reporting and oversight requirements.

It strikes me that the limitations of this process will raise serious problems for legal authority. As the Ryan Amendment demonstrates, the congressional reforms are not likely to reflect a perspective greatly different than that of existing executive practices. It is not likely that covert action abroad will be abolished; or that the FBI's Charter will prohibit political intelligence gathering. ${ }^{121}$ Although some limits will no doubt be drawn-no assassination

114. Quoted in E. Corwin, supra note 4 at 112 .

115. Senate Hearings, suprn note 102, Vol. 4, Mail Opening (1975).

116. Transcript, National Town Meeting, National Public Radio, December 11, 1975, 3.

117. 50 U.S.C. $\$ 1541-48$ (Supp IV 1974).

118. 5 U.S.C. $\$ 552$ (Supp. IV 1974).

119. 18 U.S.C. $\$ \$ 2510-20(1970)$.

120. Pub. L. No. 93-344, 88 Stat 297 (codified at scattered sections of 1, 2 and 31 U.S.C., Supp. IV 1974).

121. H.R. 6051, introduced by Rep. Herman Badillo and eighteen other legislators, would 
by the CIA or character assassination by the $\mathrm{FBI}-$ the legislative charters will probably ratify the vast bulk of executive practices. Nor should this surprise: more extensive reform would require a worldview divorced from the imperial perspective, and Congress simply does not represent that different view yet.

The attempt to "bring these agencies under the Constitution" will be limited to giving a Weberian orderliness to their activity. Of course even this effort is limited by the secrecy and license necessary to imperial policing. ${ }^{22}$ The primary limitation will be congressional reporting and oversight. Oversight gives a handful of representatives, acting for the Congress, a seat behind the executive curtain of secrecy, but on the condition that they only watch the plays, not choose which shall be performed or reveal the plot to outsiders. At present, congresspersons are enjoined from informing even their colleagues about the briefings given to them in Executive Session. Through legislated charters and oversight, the authority of Congress will be invoked to legitimate the on-going practices of the President. A section of the Congress will be folded into the executive branch, and separated from the public by official secrecy.

These representatives will face the struggle over legitimacy in concrete situations. Inevitably, they will review performances which violate their sensibilities or seem to impinge on the constitutional role of the legislature, viz. the secret war in Angola. They will individually be forced to choose between silent acquiesence (or secret remonstration which is the equivalent) and violation of their secrecy vows to speak out or leak out information. The tribulations of Rep. Michael Harrington, who revealed the CIA's "de-stabilization" in Chile suggest that few will choose the latter course. ${ }^{23}$ If they choose not to object publicly, however, they provide congressional legitimation for decisions made in secret within the executive branch, eroding the public policy-making function of the Congress.

With Congress-and inevitably the courts-ratifying and legitimating executive national security activities, I would suggest that the underlying authority of the law will be called into question. A constitution is more than its literal legal text. It is intertwined with a myth and belief structure which establishes and external system of values. Our Constitution is closely bound to the liberal theory of the law: It must be procedurally rational-publicly made by elected representatives and applied equally to all; and substantively limited-that government is the neutral arbiter, watching the interests of all, protecting them

make the necessary reforms, but its chances for passage are minimal. See H.R. 6051, 95th Cong.. lsi Sess.

122. Neuman distinguishes between public bureaucracies which follow "fixed and ascertainable" rules and private bureaucracies which follow "secret instructions." The latter tend to serve "egoistic group interests." The CIA is a private bureaucracy with governmental power. See F. Neuman, Behemoth: The Structure and Practice of National Socialism, $78-79$ (1942).

123. Harrington faced censure hearings before the House Ethics Committee: the motion was dismissed on a technicality. 
from infringement by the few or the many. Obviously, social welfare and economic legislation departed from this mythic source of authority. As suggested above, the development of administrative law bridged the gulf in part. In the national security area, however, the departure will not be so easily remedied. National security practices-even if authorized by proper procedural authority-violate basic constitutional values: that major policy decisions be publicly debated, that the state not act through private bureaucracies, that executive officials act according to law. Additionally, the daily activities themselves inherently violate widespread American norms, designedly so. The CIA's proudest moments, for example, involve large secret bribes to fix the outcome of supposedly free elections in Italy and France after World War II. ${ }^{24}$ It seems likely that "cleaning up" these activities by legislative charter will serve not to legitimate the activities but to undermine the authority of the law. Deeply felt notions of fairness and justice may be turned against the constitutional system which sanctions their violation.

Legislative charters will also not remedy the adverse example which the government will offer its citizenry. Among a growing percentage of the population. the CIA, FBI and military are considered lawless instruments of the President. They are burlesqued in cartoons, condemned in polemics, the personification of evil and corruption in novels and films. In all organs of our culture, CIA is used as a shorthand for the devious and corrupt. Legitimation of covert action will inevitably contribute to the paranoia and conspiracy fears of the citizenry. Political movements will adopt similar methods of secrecy and terror; a dialectical process which may have deterred the CIA from seeking legislative sanction earlier in its existence. Terrorism breeds counter-measures, creating the wretched spiral of repression and rebellion. In the end, the law itself will be politicized, and as Franz Neumann has written, ${ }^{25}$ "When it becomes political, justice breeds hatred and despair among those it singles out for attack. Those whom it favors, on the other hand, develop a profound contempt for the very value of justice: they know it can be purchased by the powerful."

An alternative possibility exists, of course. The national security bureaucracies can be brought within the limits of the republican constitution, not by legal legerdemain, but with a purposeful withdrawal from an imperial role abroad. There is a positive consciousness which provides the basis for this transformation. An entire segment of the politically active in this country matured not during the Cold War but in the anti-war movement, not in McCarthyite purges but in civil rights struggles. Their political motion-combined with the increasing difficulty of enforcing our order abroad-may provide the basis for a reconstitution of authority in this country.

124. See Church, supra note 15. for a similar view.

125. See Neuman. supra note 122 at 23 